\title{
October 1972
}

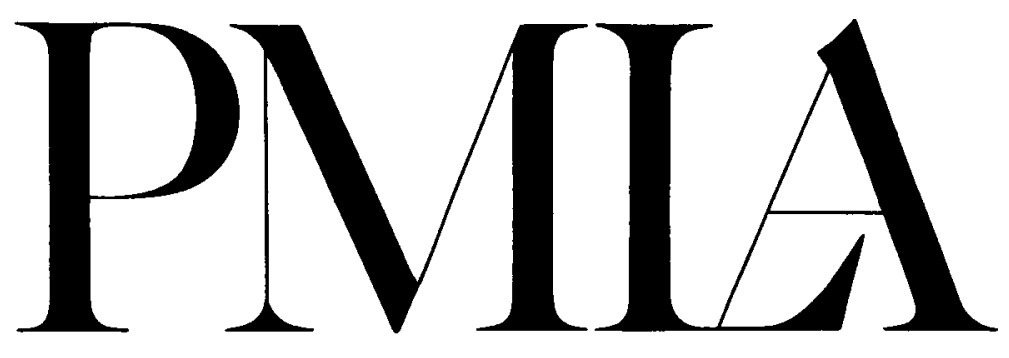

\section{Publications of the}

Modern Language Association of America 


\title{
The Modern Language Association of America
}

ORGANIZED 1883

INCORPORATED 1900

OFFICERS FOR THE YEAR 1972

President: StUart AtKins, University of California, Santa Barbara

First Vice President: FloRence Howe, State University of New York, Old Westbury

Second Vice President: JOHN HURT FISHER, University of Tennessee

Executive Secretary: William David SchaEFER

Treasurer and Deputy Executive Secretary: KenNeTH W. Mildennerger

\section{EXECUTIVE COUNCIL}

For the term ending 31 December 1972

René Girard, State Univ. of New York, Buffalo

Jean Hagstrum, Northwestern Univ.

Francis LeE UtLeY, Ohio State Unio.

For the term ending 31 December 1973

J. Hillis Miller, Yale Univ.

WALTER B. RideOUt, Univ. of Wisconsin

PaUl ScHaCH, Univ. of Nebraska
For the term ending 31 December 1974

Claudio Guillén, Univ. of California, San Diego

Margaret McKenzie, Vassar Coll.

RoberTa SALPER, State Univ. of New York, Old Westbury

For the term ending 31 December 1975

John C. Gerber, Univ. of Iowa

Olga M. Ragusa, Columbia Univ.

Helen Hennessy Vendler, Boston Univ.

\section{TRUSTEES OF INVESTED FUNDS}

\author{
Gordon N. Ray, Guggenheim Foundation, Frederick Burkhardt, American Council \\ Managing Trustee
}

C. Waller Barrett, Charlottesville, $V a$.

PMLA is issued six times a year, in January, March, May, September, October, and November, by the Modern Language Association of America, 62 Fifth Avenue, New York, New York 10011. Annual dues for membership in the Association, which includes subscription to $P M L A$, are $\$ 25$ except for the following special categories: (a) student membership at $\$ 7$, open for a maximum of four years to those who are engaged primarily in a course of study leading to a degree and who do not hold full-time teaching appointments; (b) joint husbandand-wife membership at $\$ 35$ with only one subscription to $P M L A$; (c) foreign membership at $\$ 18$, open to resident citizens of countries other than the United States and Canada.

The subscription price of PMLA for libraries and other institutions is $\$ 20$. Agents deduct $\$ 2$ as their fee. A subscription including a bound volume at the end of the year is $\$ 35$, domestic and foreign. Single copies of the January, March, May, October, and November Program issues may be obtained for $\$ 5$ each; the September Directory for $\$ 6$.

Issues for the current year are available from the MLA Materials Center. Claims for undelivered issues will be honored if they are received within one year of the publication date; thereafter the single issue price will be charged.

For information about the availability of back issues, inquire of Kraus Reprint Co., 16 East 46th St., New York 10017. Early and current volumes may be obtained on microfilm from University Microfilms, Ann Arbor, Mich. 48106. Purchase of current volumes on film is restricted to subscribers of the journal.

OFFICE OF PUBLICATION AND EDITORIAL OFFICES

62 Fifth Avenue, New York, N. Y. 10011 Tel.: 212 691-3200

All communications, including notices of changes of address, should be sent to the Membership Office of the Association at 62 Fifth Avenue, New York 10011. If a change of address also involves a change of institutional affiliation, the Membership Office should be informed of this fact at the same time.

Second-class postage paid at New Yotk, N. Y., and at additional mailing office.

Copyright (C) 1972 by The Modern Language Association of America.

Library of Congress Catalog Card Number 12-32040. 


\title{
Contents - October
}

Northrop Frye and the Problem of Spiritual Authority. Charles F. AltiERI.

\begin{abstract}
Northrop Frye's recent criticism confronts the contemporary problem raised most powerfully by the Vietnam War - can we find a telos or definition of man on which we can ground our moral reactions and our visions of human development. Frye establishes this telos by an analysis of origins. Contained in a civilization's statements of "concern," in its imaginative treatments of its own condition, one can find an underlying structure of desire which defines the ends of man. This structure and the recurrent images it produces then can serve as the middle terms people use to justify and value their actions. Frye shares his treatment of mediation with contemporary Hegelians like Sartre, Lukács, and Ricoeur, but grounds his absolute in tradition rather than in ideal absolutes or posited evolutionary patterns. Frye's idea of mediation also provides an ethical model for literary criticism: the critic tries to combine literature as product and as cultural possession by interpreting his materials as projections of imaginative desire. Furthermore, we can use Frye to criticize the relativist denial of origins in structuralist critics like Michel Foucault and Jacques Derrida. (CFA)
\end{abstract}

Contemporary Linguistics and Indo-European Studies. W. P. LEHMANN

Abstract. Recent linguistic studies, particularly the extension of structural analysis to the syntactic component of language and improved typological analysis, have made possible an increased understanding of Proto-Indo-European and the early Indo-European dialects. The new insights permit us to account for syntactic constructions such as the placement of relative clauses, adjectives, and genitives; the use of prepositions in VO, postpositions in OV languages; comparative constructions of the order STANDARD PIVOT ADJECTIVE in OV, ADJECTIVE PIVOT STANDARD in VO languages. As an illustration of a further pattern which can now be explained, the absolutes in the early dialects are examined, and accounted for as constructions that may arise in ambivalent languages. Besides contributing to an understanding of syntactic phenomena, current linguistic theory assists us in achieving further knowledge about Proto-Indo-European and further insights into the development of the Indo-European languages. (WPL)

"The Sweetness of the Twisted Apples": Unity of Vision in Winesburg, Ohio. RALPH Ciancio . . . . . . . .

Abstract. The prologue to Winesburg, Ohio, in which an old writer attributes their grotesqueness to fanaticism, oversimplifies the characters' twisted lives, but it is hardly irrelevant or at variance with the substance of the novel. The grotesques' fanatical quest for the ideal, their unwillingness to relinquish their dreams in face of the facts of experience, is at the core of all the novel's issues - its social, sexual, and mythic content-which form a philosophical whole. Yet Anderson sympathizes with his characters, for their fanaticism derives from the depths of their being and from a valid, human desire for spiritual fulfillment. The prologue also bears vitally upon the resolution of the novel's major theme-George Willard's growth in to a writer; it can be said, in fact, that the prologue brings the theme to a close. For, by the end, George has undergone a transformation of character similar to that of Dr. Reefy, whom Anderson identifies with the old writer of the prologue, and thereby comes to share the old writer's vision, which is born of the grotesque but ultimately transcends it. Indeed, symbolically at least, George is the old writer. Winesburg is his story. (RC)

\section{Visual and Spatial Imagery in Verlaine's Fêtes galantes. HaLlaM WALKER .}

Abstract. The poems of Fêtes galantes by Paul Verlaine have marked visual and musical aspects with which criticism often deals by comparing the subject matter and style of the poems with those of paintings by Watteau and music by Debussy. It is more rewarding to study similarities of basic artistic form in these works about the Rococo dream world; in particular, the visual and spatial imagery shared by Verlaine and Watteau helps elucidate 
Fêtes galantes. The vague, ambiguous, and shifting impressions sought by Verlaine are created visually by Watteau as the latter varies sharp delineation with hazy blending. The paintings tend to have either detached foreground figures or a merging of figures into a misty background. Verlaine uses these effects of detachment and merging in virtual space, verbally rendered, and coordinates them with the recurrent themes of his suite of poems. A visualized pattern along a time line results as he shifts from one effect to the other in individual works and in the total composition. Much of the musicality of the work is thus produced through visual and spatial imagery in sequence. Increased understanding of Verlaine's creation of artistic form suggests the need for study of the relationships between this form and the contents of the poems. (HW)

\section{René Char 1923-28: The Young Poet's Struggle for Communica- tion. MeChTHILd CRANSTON.}

Abstract. The poet's struggle for communication is a common theme in five of René Char's early poems, "Ce soir" (1923), "Jouvence" (1923-25), "Sillage" (ca. 1925), "Prêt au dépouillement" (ca. 1925), and "Sur le volet d'une fenêtre" (1923-25). Char passes from "mutisme" to meaningful dialogue; he learns first to see, then to listen, and, finally, to hear. Many of his mature poems will repeat this triple apprenticeship, and they are quoted to show Char's continuous concern with the necessity for dialogue. By implication this article tries to disprove Barthes's definition of modern poetry, and hopes to lead into wider considerations of the object of contemporary poetry. (MC)

\section{Syncopation in El Libro de Alexandre. DANA A. NeLSON}

Abstract. The presence of syncopation in certain words in the Libro de Alexandre (lazrar, menestral, ofrecer, sabroso, sombra, etc.) and its absence in other words (avellana, eredad, eredar, etc.) support the Castilian origin of the poem and discredit the theory of western or Leonese authorship. The preservation of the etymological medial $-d$ - in such words as porfidia, piedes, and vidieron is also dialectically significant, since the trait is particularly evident in other documents of the area of La Rioja. Similarities between the alterations introduced into Berceo's MSS and those found in the Alex are constantly stressed, since only through a clear understanding of the problems of transcription of medieval codices can we hope to clarify the question of regular meter in mester de clerecia of the thirteenth century. Scribes were capable of completely eradicating such forms as piedes (in $\mathbf{O}$ ), udió, udién, and meydía (in both $\mathrm{P}$ and $\mathrm{O}$ ). This type of obliteration has tended to confuse many critics, who are prone to base their ideas concerning the language and versification of the Alex on the MSS as they observe them, without attempting any critical analysis or reconstruction. (DAN)

\section{Sancho IV: Puente literario entre Alfonso el Sabio y Juan Ma- nuel. Richard P. KINKADE}

Abstract. Though the development of novelistic prose in medieval Castilian literature has been traditionally associated with the encyclopedic works of Alfonso el Sabio and those of his nephew, Juan Manuel, author of the Conde Lucanor, the stylistic differences between these two writers are sufficiently important to indicate the existence of a transitional period characterized by the absorption of classical rhetoric into the mainstream of religiously oriented didactic literature. An analysis of the critically neglected works of Sancho IV, second son of Alfonso and guardian to the young Juan Manuel, reveals the intermediate stages in the transformation of impersonal Alfonsine historical narrative to the highly anecdotal mode of Juan Manuel and subsequently affirms Sancho's role in Castilian letters while stressing Juan Manuel's clear genius for synthesizing the major literary currents of his age. (In Spanish) (RPK)

\section{Büchner und Trakl: Zum Problem der Anspielungen im Werk Trakls. Rudolf DiRK SCHIER}

Abstract. The fact that Georg Trakl's poetry frequently contains allusions to Hölderlin, Rimbaud, the Bible, and to various additional authors is well known. The presence of Büchner's Lenz and of some other texts in Traum und Umnachtung has, however, not yet been recognized. Some twenty-two specific passages from Lenz, adapted and modified in 


\section{Contents}

various ways, occur in the second section of Traum und Umnachtung. In addition, Trakl paraphrases texts by Nietzsche in the first section and cites Hölderlin in the third; the last section comprises most of the major themes from Trakl's own work. The concentration of allusions to a specific author in single sections of Traum und Umnachtung suggests that Trakl's use of citations is conscious. Such a recognition does not involve an "intentional fallacy": the author's intention, in incorporating allusions and quotations into his work, is comparable to his intention in choosing a certain kind of form. Both citations and forms can be identified with the proper training: a work of literature containing conscious allusions (Zitatendichtung) must be treated as a literary form in its own right, in which even simple, apparently descriptive phrases no longer refer to objects or experiences, but to the tradition of poetic language. (In German) (RDS)

\section{Crime and Myth: The Archetypal Pattern of Rebirth in Three Novels of Dostoevsky. AlexandRa F. Rudicina .}

Abstract. The focal dimension of Dostoevsky's creative effort in his later period is his compelling esthetic and metaphysical concern with ultimate violence, particularly in its doctrinaire or ideological aspect. The act of murder is seen as a "crime of reason," an outgrowth of modern man's autarkic intellect. It is this "crime of reason" in accordance with his metaphysical esthetics that Dostoevsky constitutes as the transgression but also a potential felix culpa leading through suffering and expiation to ultimate rebirth. Crime and Punishment, The Possessed, and The Brothers Karamazov each present an individuated version of this archetypal scheme. Raskolnikov emerges at the end of Crime and Punishment on the threshold of "a new life." In The Possessed, Stavrogin's potentially "positive" performance perverts itself into "a quest for damnation." Dmitri Karamazov undergoes spiritual regeneration even though falling short of complete redemption. In thus restating the timeless relevance of the archetypal pattern of rebirth through sin and expiation. Dostoevsky brings a mythical perspective to his vision of the Russia of his time. (AFR)

The Theme and Structure of the Stanzaic Morte Arthur. RicHARD A. WERTIME

Abstract. Though not a wholly successful work, the Stanzaic Morte Arthur is more coherent, more serious in intent, than is usually acknowledged. Dramatically and thematically organized in terms of the opposition between Launcelot and Gawayne, the work is best described as "tragedy of consequence." Launcelot's adultery with Gaynour is ostensibly the root cause of the destruction of Arthur's realm, but the poet transfers the principal blame to others, above all to Gawayne. He achieves this by (a) distinguishing the adultery itself from its revelation to Arthur; (b) depicting the illicit love as favorably as possible; and (c) creating an implicit duality in the characters of Launcelot and Gawayne. The two undergo a reversal of primary roles by which Gawayne becomes the aggressor and Launcelot the placator. As the hero, Launcelot comes to embody the wiser course of actionwithdrawal from worldly conflict - which leads him, eventually, to the priesthood. Confusion, however, results from the viewpoint of the narrator, who seems so indiscriminately generous with his praise that he contradicts the obvious implications of the course of events. This difficulty is resolved when one understands that the narrator's compassion transcends, not contradicts, the rigorous justice of events. (RAW)

\section{Sterne's Rabelaisian Fragment: A Text from the Holograph Manuscript. MELVYN NEW}

\footnotetext{
Abstract. Laurence Sterne's "Fragment in the Manner of Rabelais" was first published seven years after Sterne's death. A collation of that edition with the holograph MS preserved in the Pierpont Morgan Library reveals that the text is bowdlerized, with no pretense to accuracy or integrity. Moreover, all subsequent reprintings of the fragment, including the standard editions of 1904 and 1927, merely copy this inaccurate text. The edition presented here represents, then, an effort to provide the first true text of Sterne's Rabelaisian fragment. In addition, the Introduction makes use of several canceled passages to argue that the fragment should be dated one year earlier than previously supposed (1759 rather than 1760 ); if correct, this new date suggests that the fragment was Sterne's first creative attempt after his success with the Political Romance. As such, it deserves a significant place in the Sterne canon. (MN)
} 
"Count Guido Franceschini": The Villain as Artist in The Ring and the Book. MiCHAEL G. YETMAN

Abstract. Book v of The Ring and the Book affords us a view of Guido Franceschini very different from that provided by his second monologue. This difference is accountable to the fictive rhetorical method that Guido employs in confronting the judges at his murder trial. In Book Xr, having failed in his attempt to prolong life through fiction, Guido resorts to what he calls a more "voluble rhetoric" of the soul, thus becoming accessible to us for the first time in the same way that we see the other speakers in the poem. An analysis of Guido's fiction in Book v, especially his rendering of Caponsacchi, Pompilia, and himself, as the hero, heroine, and wronged husband, respectively, of popular medieval and renaissance literature reveals a conception of art as deception, contrary to Browning's informing belief in art as a means of arriving at truth by heightening rather than distorting reality. A comparison of Book XI with the earlier monologue indicates that, in addition to making plain the enormity of his villain's evil nature, Browning uses Guido's second monologue as an implicit repudiation of what he considers to be the specious theory of art that Guido relies upon in Book v. (MGY)

\section{Prufrock and After: The Theme of Change. ElisabeTH SchNeI-} DER

Abstract. T. S. Eliot not only changed his beliefs radically during the course of his life; he also set himself, as a continuing theme in certain of his major poems, to explore the painful and difficult process of subjective change itself in its relation to the will. Prufrock and The Waste Land ask whether change is possible, with differing answers; most of the 1927-31 poems explore change as it is being subjectively experienced; the later poems and plays remain concerned with the theme but more perfunctorily. Though scarcely touched upon in his prose writings, this process of inner change, individual not social, is a major unifying theme in Eliot's poetry. (ES)

Notes, Documents, and Critical Comment: 1. The Inside Front and Back Covers of Whitman's Earliest Known Notebook: Some Observations on Photocopy and Verbal Descriptions. ESTHER SHEPHARD

Abstract. Enlargement prints made by the Library of Congress from a privately owned microfilm of Whitman's "Earliest" Notebook (Holloway No. 1) have been consulted, and two prints (the inside front and back covers of the Notebook) are compared, in detail, with descriptions of these pages in scholarly publications in the Whitman field. (ES)

Forum . . . . . . . . . . . . . . . . . II 23

Forthcoming Meetings and Conferences of General Interest . . . II 34

Professional Notes and Comment . . . . . . . . . . . 1138 


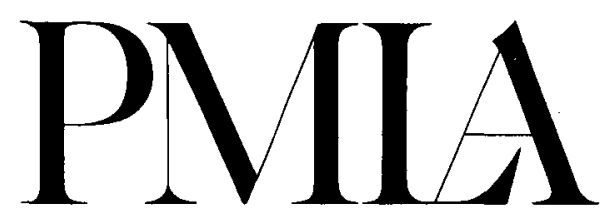

\title{
PUBLICATIONS OF THE MODERN LANGUAGE ASSOCIATION OF AMERICA
}

Published Six Times a Year

Indices: Vols. 1-50, 1935; 51-60, 1945; 51-79, 1964

\section{EDITORIAL COMMITTEE}

David M. Bevington, 1974

University of Chicago

A. Dwight Culler, 1974

Yale University

Richard Ellmann, 1973

Oxford University

VICTOR ERLICH, 1974

Yale University

Donald J. GREene, 1973

University of Southern California

Stanley B. GreEnFIEld, 1975

University of Oregon

JUDD D. HUBERT, 1976

University of California, Irvine

CECIL Y. LANG, 1973

University of Virginia

JAMES E. Miller, JR., 1973

University of Chicago
J. Mitchell Morse, 1974

Temple University

William G. Moulton, 1975

Princeton University

STEPHEN G. Nichols, JR., 1974

Dartmouth College

PAUl R. Olson, 1974

Johns Hopkins University

Allen W. Phillips, 1976

University of Texas

EARL R. WASSERMAN, 1975

Johns Hopktns University

KATHLEEN WILLIAMS, 1975

University of California, Riverside

Nathalia Wright, 1975

University of Tennessee

THEODORE J. ZIOLKOWSKI, 1975

Princeton University

\section{Editor: WiLliam David Schaefer}

\author{
Managing Editor: WillaAm Pell \\ Assistant Editor: JUDY GouldING \\ Advertising Coordinator: JUDTH LAPIDUS \\ Editorial Assistant: MARGOT RABINER
}

\section{A STATEMENT OF EDITORIAL POLICY}

$P M L A$ endeavors to present distinguished contemporary scholarship and criticism in all fields of the modern languages and literatures. The distribution of papers should reflect the work actually being done from year to year, regardless of periods or languages. Members who feel their interests neglected by this policy are urged to write and to encourage others to write publishable articles.

$P M L A$ welcomes either new or traditional approaches by either young or established scholars. It urges authors to bear in mind that their audience is the entire membership of the Association and to strive to communicate the broader implications as well as the precise substance of their research. Articles should be written in a clear, concise, and attractive style, with documentation held to a minimum. PMLA does not encourage notes or long articles; it does not review books.

Any member of the Association may submit papers to $P M L A$. Each paper submitted will be sent to at least one consultant reader and one member of the Editorial Committee. An abstract in English on the standard form must accompany every article submitted. Abstract forms and guidelines may be obtained from the Editor.

Manuscripts, prepared in conformity with the second edition of the MLA Style Sheet, should be addressed to the Editor of $P M L A, 62$ Fifth Avenue, New York, N. Y. 10011. Copies are not needed, but should be made and retained by the author. Pamphlets On the Publication of Research and on The Publication of Academic Writing may be purchased from the MLA Materials Center. 